\title{
关于水利水电工程建设征地移民安置工作的思考
}

\author{
王慧 \\ 水利部新疆维吾尔自治区水利水电勘测设计研究院 \\ DOI:10.32629/hwr.v3i3.1983
}

[摘 要] 水利水电工程建设征地移民安置工作是工程施工建设中极为重要的一环。通过该项工作,不仅能够保障水利工程施 工建设的正常开展, 同时也能够解决征地给当地居民造成的影响, 保障移民的正常利益。在本文中, 笔者将阐述当前水利水电工 程建设征地移民安置工作中存在的问题,并由此提出改善策略,希望对未来移民安置工作的开展有所帮助。

[关键词] 水利水电工程; 建设; 移民安置; 思考

众所周知, 水利水电工程的施工建设是我国基础建设中 不可缺少的一环。在水利水电工程的建设中, 除了要重视工 程施工质量以外, 还有一件十分重要的工作, 那就是征地移 民安置工作。征地移民安置工作是一项十分重要的工作, 对 国民的生活以及社会的和谐稳定有着巨大影响。然而, 从当 前水利水电工程建设征地移民安置工作实际的开展情况来 看, 可以发现还存在着一些问题需要解决。

\section{1 当前水利水电工程建设征地移民安置工作存在的问题}

1.1 缺乏统一的法律法规

从当前水利水电工程建设征地移民安置工作实际的开 展情况来看, 首先可以发现缺乏统一的标准和法规。虽然目 前我国已经出台了相关政策, 希望以此能够保障被征地居民 的正常利益。然而, 在实际执行过程中却出现了各式各样的 问题。其中, 缺乏统一的标准和规范, 使得不同地区、居民的 补偿存在较大差异。这种差异不仅会加大政府相关部门的负 担, 同时很容易引起不同地区移民之间的攀比心理。从而阻 碍了移民安置工作的开展。同时, 缺乏统一的标准和规范, 也导致许多移民安置工作缺乏公平性, 在社会上造成极为不 良的影响, 威胁社会的和谐与稳定 ${ }^{[1]}$ 。

1.2 缺乏有效的前期准备工作

缺乏有效的前期准备工作同样是当前水利水电工程建 设征地移民安置工作开展过程中存在的严重问题之一, 该问 题主要表现在四个方面。首先, 从政府以及相关部门来看, 对移民安置工作没有足够的重视, 从而导致了统一标准以及 法规的缺乏, 使得移民安置工作缺乏强而有力法律法规的支 持。其次, 从设计单位来看, 由于移民安置工作通常要涉及多 个单位、多个部门以及大量人员, 因此安置工作十分复杂且繁 琐, 这就导致工作的开展十分混乱。再次, 从施工单位的角度 来看, 由于移民安置工作的周期较长。但是, 施工单位希望能 够尽快施工, 追赶工程进度, 同时也是为了自身经济利益 ${ }^{[2]}$ 。因 此, 在施工时会忽视移民的知情权与参与权, 这样一来很容易 引起移民的反感, 从而影响整个工作的正常开展。最后, 从监 理单位来看。在进行移民安置工作时, 监理单位原本应当要 进行全程监督和控制, 确保移民的正常权益, 督促整个工作 的正常开展。然而, 在实际工作中, 监理单位的工作往往停留
在表面, 没有真正发挥作用, 这就导致整个移民安置工作的 开展缺乏有效的监督和管理。

1.3 缺乏有效组织管理工作

从当前水利水电工程建设征地移民安置工作实际的开 展情况来看, 同样缺乏高效的组织管理工作。众所周知, 移民 安置工作绝对不是某一个单位或者某几个单位能够完成的, 而是需要各个单位, 包括水电企业、各级政府、相关部门以 及施工单位共同参与进来。然而, 在实际工作中, 各个单位之 间的工作缺乏良好的协调管理工作。这样一来, 不仅会混淆 各部门、职业之间的权责混乱, 同时也会阻碍工作的落实与 执行, 极大影响移民安置的工作效率 ${ }^{[3]}$ 。

\section{4 移民后续生活得不到保障}

移民后续生活得不到保障同样是当前移民安置工作中 存在的严重问题之一。对于移民而言, 除了要给予经济补偿 以外, 更重要的是要保障他们后续的正常生活。然而, 当前的 移民安置工作往往忽视了这一点, 仅仅只是短期补偿, 缺乏 后续生活的保障措施。这样一来, 就极大损害了移民的合法 利益, 也容易让移民对未来产生恐慌与不确定感, 从而影响 移民安置工作的开展。

\section{5 资金问题}

在移民安置工作中, 经常会产生资金问题。这是因为, 移 民安置工作通常是在水利水电工程建设完成之后再进行。这 就导致移民安置工作的资金经常出现不足或者短缺的问题。 虽然政府以及相关部门出台了相关法律法规对移民进行资金 上的补偿。但无论是资金还是移民新房建设所需要的资金往 往会因为各种原因滞后或者无法到位。这样一来, 极大的损害 了移民的利益。给社会的和谐稳定带来极为不良的影响。

\section{2 改善当前水利水电工程建设征地移民安置工作现状} 的策略

\section{1 经济安置}

要想改善当前水利水电工程建设征地移民安置工作的 现状, 首先需要做的就是做好经济安置工作。当前我国移民 补偿政策是根据移民的经济损失情况给予资金和物质上的 补偿。这种补偿方式虽然能在一定程度上表现出公平性, 但 事实上并不能解决移民贫困化的问题。这是因为, 此类补偿 
属于短期性补偿, 没有考虑到移民生活的可持续发展。所谓 授人以鱼不如授人以渔, 只有让移民拥有生产性收入才能改 善移民的贫困化问题。因此, 所谓的经济安置指的就是要将 原本的资金与物质补偿调整为两种形式, 分别是前期补偿和 后期补偿。所谓的前期补偿指的就是在移民搬迁前或者搬迁 的时候给予一次性的资金和物质补偿, 帮助他们短期内的生

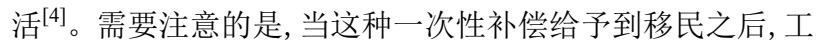
程方对移民对安置责任基本解除。而后期补偿指的就是当移 民到达安置地区之后给予他们生产和发展的机会。通过这种 方式让移民能够拥有生产性收入, 这样才能有效解决移民贫 困化问题, 保障移民的正常生活, 维护社会的和谐与稳定。

\section{2 社会安置}

社会安置对于改善当前移民安置问题也有着极为重要 的作用。在移民安置工作中, 经济安置能够帮助移民解决生 存问题。但是, 这并不意味着在移民安置工作中, 解决经济问 题就足够了。这是因为, 人是出于社会群体之中, 不同的社会 也孕育出了不同的文化风俗。因此, 移民安置工作还需要确 保移民能够融入到新的环境中, 同时还能够保存自身的文化 习惯。只有这样, 才能保障社会的安全和稳定, 同时维护文化 的多样性 ${ }^{[5]}$ 。而要做到这一点, 主要可以从三个方面出发。 首先, 需要通过政治平等的方式促进移民文化与当地文化的 融合。这是因为, 如果缺乏政治上的平等, 那么无论对移民还 是原住民都是极为不公正的, 同时也容易引发民众的不满。 其次, 要鼓励移民参与当地的社会活动。通过这样的方式能 够让移民更加快速的融入到当地环境中, 并且提升他们的归 属感。最后, 是要重视移民自身的能力素质与心理素质。这 是因为, 移民需要融入到新的文化环境中, 只有让他们在新 的环境中取得成就感和安全感, 才能让他们更加积极主动的 迎接新生活, 避免排斥新环境的情况出现。

\section{3 生态安置}

要想进一步个改善水利水电工程建设征地移民安置工 作的问题, 还需要重视生态安置工作。通过生态安置工作能
够平衡移民与生态环境之间的关系, 实现二者的平衡。而要 做到这一点, 需要重视三个方面的工作。第一点, 需要重视的 是移民安置区的水土保护问题。通过水土保护工作, 不仅能 够为移民的居住创造一个更加舒适的环境, 同时也能够维护 安置区的安全和稳定, 保障移民的正常生活。第二点, 就是要 解决移民安置区的环境容量问题。众所周知, 生态环境的容 量有限。如果超过限额, 那么人类活动就会极大影响生态环 境, 导致环境被破坏。因此, 在开展移民工作时, 一定要充分 考虑安置区的环境容量问题, 避免人口密度过大给环境造成 极大负担。最后, 要建立一套完善的安置区环境保护管理体 系。痛殴该体系来维护安置区的生态平衡, 让移民能够拥有 一个更好的生活环境。

\section{3 结束语}

综上所述, 在水利水电工程的施工建设中, 除了要保障 工程施工质量以外, 还需要重视移民的安置工作。从当前移 民安置工作存在的问题来看, 要想进一步提高安置工作质量 和效率, 就必须要做到三点, 分别是经济安置、社会安置以及 生态安置工作。只有这样, 才能给移民创造一个更加舒适的 生活环境, 保障移民的正常生活, 避免移民贫困化的出现, 从 而维护社会的和谐与稳定, 为我国社会经济的发展建设做出 更大贡献。

\section{[参考文献]}

[1]金金冰利水电工程建设征地移民安置工作的思考 [J].河南水利与南水北调,2018,47(07):95-96.

[2]陈鹏飞,郑国忠.水利水电工程建设征地移民安置工 作中的问题与对策 [J]. 企业技术开发,2014,33(1):158-159.

[3] 阴奔,梁炳华.水利水电工程建设征地移民安置规划 设计监理工作探讨[J].水利水电工程设计,2017,36(1):34-37.

[4]赵瑾.水利水电工程建设移民安置规划设计分析[J]. 广东科技,2013,22(24):163+132.

[5]吴欢欢,朱恒.当议水利水电工程建设征地移民安置 中的问措施[J].环球市场,2017,(13):131. 